\title{
REVIEW
}

\section{The impact of Disrupted-in-Schizophrenia 1 (DISC1) on the dopaminergic system: a systematic review}

\author{
T Dahoun $^{1,2,3}$, SV Trossbach ${ }^{4}$, NJ Brandon ${ }^{5}$, C Korth $^{4}$ and OD Howes B $^{1,2,3,6}$
}

Disrupted-in-Schizophrenia 1 (DISC1) is a gene known as a risk factor for mental illnesses possibly associated with dopamine impairments. DISC1 is a scaffold protein interacting with proteins involved in the dopamine system. Here we summarise the impact of DISC1 disruption on the dopamine system in animal models, considering its effects on presynaptic dopaminergic function (tyrosine hydroxylase levels, dopamine transporter levels, dopamine levels at baseline and after amphetamine administration) and postsynaptic dopaminergic function (dopamine D1 and D2 receptor levels, dopamine receptor-binding potential and locomotor activity after amphetamine administration). Our findings show that many but not all DISC1 models display (1) increased locomotion after amphetamine administration, (2) increased dopamine levels after amphetamine administration in the nucleus accumbens, and (3) inconsistent basal dopamine levels, dopamine receptor levels and binding potentials. There is also limited evidence for decreased tyrosine hydroxylase levels in the frontal cortex and increased dopamine transporter levels in the striatum but not nucleus accumbens, but these conclusions warrant further replication. The main dopaminergic findings are seen across different DISC1 models, providing convergent evidence that DISC1 has a role in regulating dopaminergic function. These results implicate dopaminergic dysregulation as a mechanism underlying the increased rate of schizophrenia seen in DISC1 variant carriers, and provide insights into how DISC1, and potentially DISC1-interacting proteins such as AKT and GSK-3, could be used as novel therapeutic targets for schizophrenia.

Translational Psychiatry (2017) 7, e1015; doi:10.1038/tp.2016.282; published online 31 January 2017

\section{INTRODUCTION}

The Disrupted-in-Schizophrenia 1 (DISC1) gene was originally discovered at the breakpoint of a balanced translocation $t(1 ; 11)$ (q42;q14.3) in a Scottish family and later identified in a North American family with high rates of schizophrenia. ${ }^{1-4}$ Since then, preclinical models have shown that DISC1 mutant animals exhibit behavioural, neurostructural and neurochemical features relevant to schizophrenia, 5,6 although its significance for the human disease has been debated. ${ }^{7-9}$ DISC1 is described as a scaffold protein with multiple interactors involved in a wide range of cellular processes including neurotransmitter signalling. ${ }^{10,11}$ In particular, DISC1 is known to interact with several proteins involved in dopamine signalling including fasciculation and elongation protein zeta 1, phosphodiesterase 4D9 and phosphodiesterase $4 \mathrm{~B}$, serine/threonine protein kinase Akt and glycogen synthase kinase-3 (GSK-3) ${ }^{12-16}$ as well as synaptic interactors such as kalirin7 and the Traf2, Nck-interacting kinase, ${ }^{17,18}$ and the microtubule/ centrosomal proteins pericentriolar material 1 and Bardet-Biedl syndrome protein. ${ }^{19,20}$ These multiple interactions have highlighted the potential of DISC1 as a therapeutic target. ${ }^{21-23}$

The neurotransmitter dopamine is widely thought to have a central role in the aetiology of psychotic disorders. ${ }^{24-26}$ The dopamine hypothesis of schizophrenia was initially based on the findings that the affinity of antipsychotic medications for dopamine receptors is closely related to their clinical potency, ${ }^{27-29}$ and that drugs that increase dopamine levels provoke psychotic symptoms in healthy people. ${ }^{30,31}$ Molecular imaging studies since then have shown increased presynaptic dopamine synthesis capacity and release in schizophrenia ${ }^{32-35}$ and in subjects with prodromal symptoms of schizophrenia. ${ }^{36-39}$ Alterations in dopamine D1 and D2/3 receptors, tyrosine hydroxylase (TH) levels and baseline synaptic dopamine levels in schizophrenia have also been reported, ${ }^{40,41}$ although with some inconsistency. ${ }^{42}$

These findings highlight why dopaminergic dysfunction has a pivotal role in schizophrenia. In view of this, we sought to review the evidence from animal models that DISC1 pathway alterations may impact on dopaminergic function, as it has not been comprehensively synthesised before. The aim of our review was therefore to summarise the impact of DISC1 on TH levels, dopamine transporter (DAT) levels, basal dopamine levels and after amphetamine administration, dopamine D2 receptor-binding potential (BP), dopamine D1 (D1R) and D2 receptor (D2R) levels, and locomotor activity after amphetamine administration for dopamine-related behaviour. ${ }^{43}$ We selected publications citing data collection in the midbrain, as this is the location of the majority of dopaminergic neuron cell bodies in the brain, and the frontal cortex, hippocampus and striatum as these are the target sites of the main dopaminergic pathways relevant to psychiatric disorders. ${ }^{44,45}$

\footnotetext{
${ }^{1}$ Psychiatric Imaging Group MRC London Institute of Medical Sciences, Hammersmith Hospital, London, UK; ${ }^{2}$ Institute of Clinical Sciences, Faculty of Medicine, Imperial College, Hammersmith Hospital, London, UK; ${ }^{3}$ Department of the Institute of Clinical Sciences, Psychiatric Imaging Group, MRC London Institute of Medical Sciences (LMS), Imperial College-Hammersmith Hospital Campus, London, UK; ${ }^{4}$ Department of Neuropathology, Medical Faculty, Heinrich Heine University Düsseldorf, Düsseldorf, Germany; ${ }^{5}$ AstraZeneca Neuroscience, Innovative Medicines and Early Development Biotech Unit, R\&D Boston, Waltham, MA, USA and ${ }^{6}$ Department of Psychosis Studies, Institute of Psychiatry, Neurology and Neuroscience (loPPN), King's College London, London, UK. Correspondence: Dr T Dahoun, Psychiatric Imaging Group, MRC London Institute of Medical Sciences (LMS), Imperial College-Hammersmith Hospital Campus, London W12 0NN, UK.
}

E-mail: t.dahoun14@imperial.ac.uk

Received 21 July 2016; revised 16 November 2016; accepted 27 November 2016 


\begin{tabular}{|l|l|}
$\begin{array}{l}65 \text { articles } \\
\text { identified by } \\
\text { search }\end{array}$ \\
\end{tabular}$\longrightarrow \begin{aligned} & 33 \text { articles excluded } \\
& -24 \text { reviews } \\
& -4 \text { articles not in English } \\
& -5 \text { human studies with no dopamine measures }\end{aligned}$



14 articles

included in

systematic review

Figure 1. Flow chart of identification, exclusion and inclusion of eligible studies. DISC1, disrupted-in-schizophrenia 1.

\section{MATERIALS AND METHODS}

Selection of studies

The entire PubMed database was searched to select publications. Studies were screened based on the terms ('Disrupted-inSchizophrenia-1' OR 'DISC1') AND ('dopamine' OR 'tyrosine hydroxylase' OR 'dopamine receptor' OR 'DAT' OR 'amphetamine' OR 'behavioral alterations' OR 'locomotor activity' OR 'Positron Emission Tomography' OR 'PET' OR 'Single Photon Emission Computed Tomography' OR 'SPECT'). Only articles meeting the following criteria were included: (1) original studies; (2) English language; (3) peer-review journals; (4) findings reporting TH levels, DAT levels, basal dopamine levels and/or dopamine levels after amphetamine administration, and/or dopamine receptor-binding potential, dopamine receptor levels and/or locomotion after amphetamine administration in a DISC1 model compared with a control group; and (5) in the frontal cortex, striatum, nucleus accumbens, midbrain and/or hippocampus, as these regions are major target sites of dopaminergic projections in the brain and are thought to be involved in the pathophysiology of schizophrenia. ${ }^{44,45}$ The DISC1 models were selected based on gene mutation in DISC1 or alteration in the quantitative expression of DISC1 protein. Method and results sections of the eligible articles were screened to identify the measures of interest listed above.

\section{Data extraction}

The main outcome measures were the differences between the DISC1 models and controls in (1) TH levels; (2) DAT levels; (3) basal dopamine levels; (4) dopamine levels after amphetamine administration; (5) dopamine receptor-binding potential; (6) D1R and D2R levels; and (7) locomotion after amphetamine administration. In addition, the following data were extracted: (8) authors; (9) year of publication; (10) the DISC1 model; (11) samples size; and (12) methods. The data were extracted by TD and checked by SVT. Findings related to the nucleus accumbens and olfactory tubercle were merged as both being part of the ventral striatum. ${ }^{46}$

\section{RESULTS}

Fifty-one studies were excluded from a total of 65 studies screened (Figure 1). Fourteen studies were included of which two were of TH levels, three of DAT levels, nine of basal dopamine levels, six of induced dopamine release, four of dopamine receptor $B P$, four studies of D1R levels, four studies of D2R levels and thirteen of locomotion after amphetamine administration. Table 1 summarises all studies including the DISC1 model used, sample sizes and methods. It should be noted that we were not able to find evidence that dopaminergic function had been investigated in more recently disclosed DISC1 models, for example. ${ }^{47,48}$

\section{DISC1 models}

Five types of DISC1 models were identified across the studies as follows: (1) transgenic expression of truncated human Disc1 protein with dominant-negative (DN) effect; (2) DISC1 haploinsufficiency/silencing; (3) full-length human DISC1 overexpression; (4) artificial Disc1 mutation; and (5) wild-type model (Table 1). Data on locomotion after amphetamine administration from Su et al. ${ }^{62}$ were included despite the absence of a direct comparison between mutant and wild-type mice as they showed a functional relationship between Disc1 and the dopamine receptor. Both genotype effects (wild type versus transgenic) and genotype effect in a stress condition (isolated wild type versus isolated transgenics) were included from Niwa et al..$^{51}$

\section{TH levels}

Two studies investigated TH levels in the hDISC1 and the Disc1 RNA interference (RNAi)/silencing models compared with controls. ${ }^{51,54}$ These studies showed reduced TH levels in frontal cortical regions in isolated $h D I S C 1$ mice compared with isolated controls $^{51}$ and in the Disc1 RNAi/silencing model compared with controls $^{54}$ (Figure 2 and Table 3).

One study showed no significant changes in $\mathrm{TH}$ levels between hDISC1 and controls, and between isolated hDISC1 mice and isolated controls in the nucleus accumbens. ${ }^{51}$

\section{DAT levels}

Three studies investigated DAT levels in the DISC1 model compared with controls. ${ }^{52,56,58}$ Two studies found increased DAT levels in the striatum of DN homozygous line 37 mice and tgDISC1 rats compared with controls Tables 2 and 3. ${ }^{52,58}$

One study found no significant difference between the Disc1 $\Delta 2-3$ mice compared with controls in the nucleus accumbens. $^{56}$

\section{Basal dopamine levels}

Nine studies investigated basal dopamine levels in DISC1 models compared with controls. ${ }^{49-52,54,56,58,59,61}$ In vivo microdialysis and post-mortem high-performance liquid chromatography with electrochemical detection (HPLC-ED) were used, measuring extracellular and total dopamine levels, respectively.

Eight studies investigated basal dopamine levels in the frontal cortex/mPFC, six using HPLC-ED ${ }^{49,50,55,58,59,61}$ and two using both post-mortem HPLC-ED and microdialysis. ${ }^{51,54}$ One of the two studies using microdialysis showed decreased basal dopamine levels in the Disc1 RNAi/silencing model compared to controls, ${ }^{54}$ whereas the other study found no significant changes between the $h D I S C 1$ mice and controls and the isolated hDISC1 mice and isolated controls. ${ }^{51}$ For HPLC-ED, decreased basal dopamine levels were found at postnatal day 56 in the Disc1 RNAi/silencing model, ${ }^{54}$ and in males from the prenatal $h D I S C 1$ expression group (until embryonic day 17), the postnatal expression group (from embryonic day 17 on) groups and the pre- and postnatal hDISC1 expression (entire life) compared with controls. ${ }^{49}$ No significant differences were reported in the other studies. ${ }^{50,51,55,58,59,61}$

Six studies investigated basal dopamine levels in the striatum using HPLC-ED ${ }^{49-51,55,58,61}$ and one using both HPLC-ED and microdialysis. ${ }^{59}$ One study found decreased total dopamine levels in the full-length DISC1-overexpressing rat model compared with controls in the dorsal striatum. ${ }^{58}$

Six studies investigated basal dopamine levels in the nucleus accumbens, one using in vivo microdialysis, ${ }^{52}$ four using 


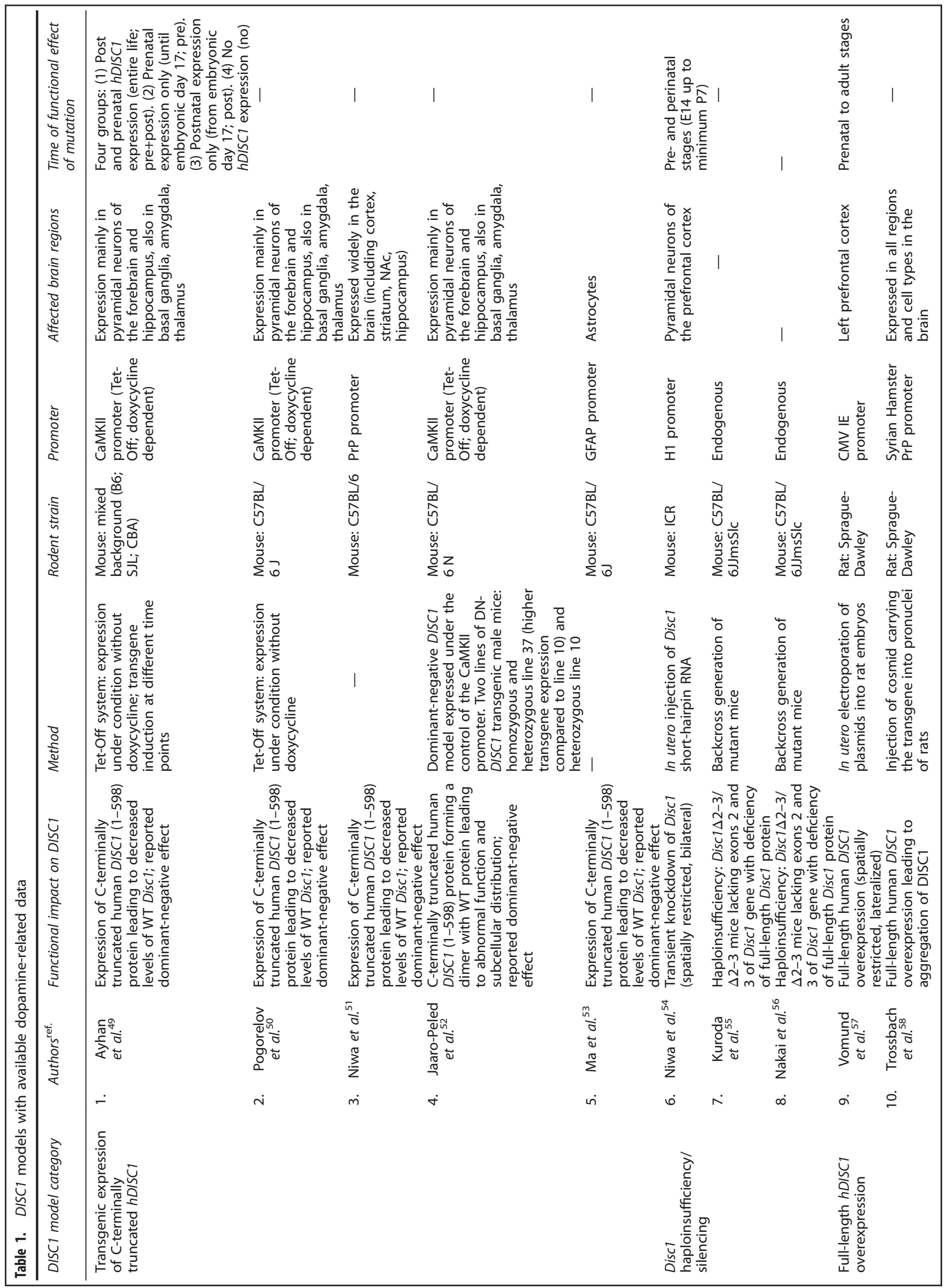




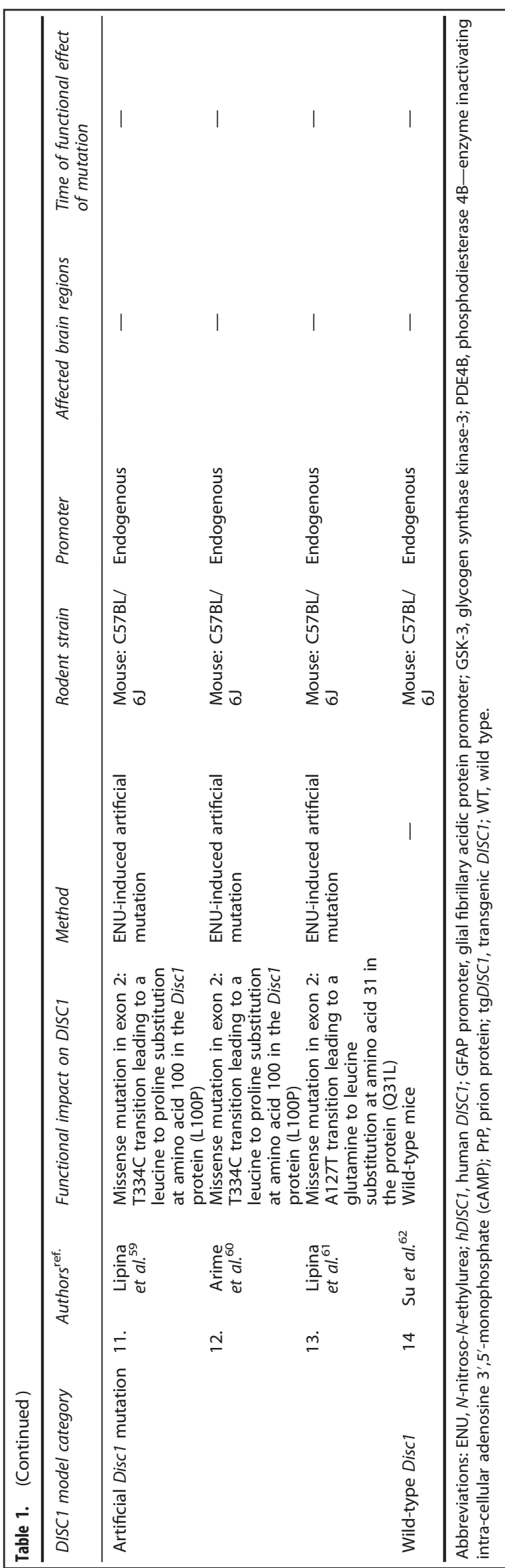

HPLC-ED $49,58,59,61$ and one using both techniques. ${ }^{54}$ Two studies using in vivo microdialysis showed decreased basal dopamine levels in the Disc1 RNAi/silencing model compared with controls ${ }^{54}$ and the hDISC1 heterozygous line 10 and 37 mice compared with controls. $^{52}$ One study using HPLC-ED showed significant decreased basal dopamine levels in L100P ENU-generated missense mutation mice, ${ }^{61}$ whereas the others found no significant differences. ${ }^{49,54,58,59}$

One study investigated basal dopamine levels in the midbrain and found no significant difference between the Disc1 $\Delta 2-3$ haploinsufficiency model and controls. ${ }^{55}$

Seven studies investigated basal dopamine levels in the hippocampus using HPLC-ED. ${ }^{49,50,54,55,58,59,61}$ One study found decreased dopamine levels in females in the postnatal hDISC1 expression group compared with prenatal expression only and controls. ${ }^{49}$ The other studies found no significant differences. $50,54,55,58,59,61$

\section{Induced dopamine release}

All the studies induced dopamine release by administrating amphetamine-related drugs. Two studies investigated induced dopamine release in the frontal cortex and found no significant differences, one using microdialysis ${ }^{51}$ and one using HPLC-ED. ${ }^{50}$

One study investigated induced dopamine release in the striatum using in vivo microdialysis ${ }^{59}$ and one study using HPLC$\mathrm{ED},{ }^{50}$ both reporting no significant differences.

Four studies investigated induced dopamine release in the nucleus accumbens using microdialysis. ${ }^{51,52,54,56}$ The four studies found significantly increased dopamine release. This was in the DISC1 knockdown compared with controls, ${ }^{54}$ in isolated hDISC1 compared with isolated controls, ${ }^{51}$ in heterozygous line 10 and 37 compared with controls 52 and female but not male Disc1 $1 \Delta 2-3$ mice compared with controls. ${ }^{56}$

One study investigated induced dopamine release in the hippocampus using HPLC-ED and found no significant difference between the hDISC 1 and controls. ${ }^{50}$

\section{Dopamine D1 receptor}

Two studies investigated D1R levels in the frontal cortex and found no significant differences between the $h D I S C 1$ and controls, and the Disc1 $\triangle 2-3$ haploinsufficiency model and controls. ${ }^{51,56}$

Three studies investigated D1R levels in the striatum. ${ }^{52,56,58}$ One study found increased levels in the hDISC1 model compared with controls, ${ }^{52}$ whereas the others found no significant differences. $^{56,58}$

Two studies investigated D1R levels in the nucleus accumbens. ${ }^{51,56}$ One study found significant increased D1R levels in female and no significant changes in male and mixed Disc1 $\Delta 2-3$ groups, ${ }^{56}$ whereas the other showed no significant differences. ${ }^{51}$

\section{Dopamine D2 receptor}

Three studies investigated D2R levels in the frontal cortex. ${ }^{51,54,56}$ One study found significant increased D2R levels in the hDISC1 mice compared with controls and isolated hDISC1 mice compared with isolated controls ${ }^{51}$ and the two other studies found no significant differences between the Disc1 RNAi/silencing/haploinsufficiency models and controls. ${ }^{54,56}$

Two studies investigated D2R levels in the striatum. ${ }^{52,56}$ The hDISC1 mice showed significant increased D2R levels, ${ }^{52}$ whereas the other showed no significant differences between the Disc1 $\Delta 2$ 3 models and controls. ${ }^{56}$

Four studies investigated dopamine receptor-binding potential in the striatum. ${ }^{50,52,58,59}$ The dopamine D2 receptor is known to exist in two interconverting states, a low-affinity $(\mu \mathrm{m})$ and a highaffinity (nm) state. ${ }^{63}$ Lipina et $a .^{59}$ and Trossbach et al. ${ }^{58}$ found a significant increase in dopamine D2 high-affinity receptor levels 


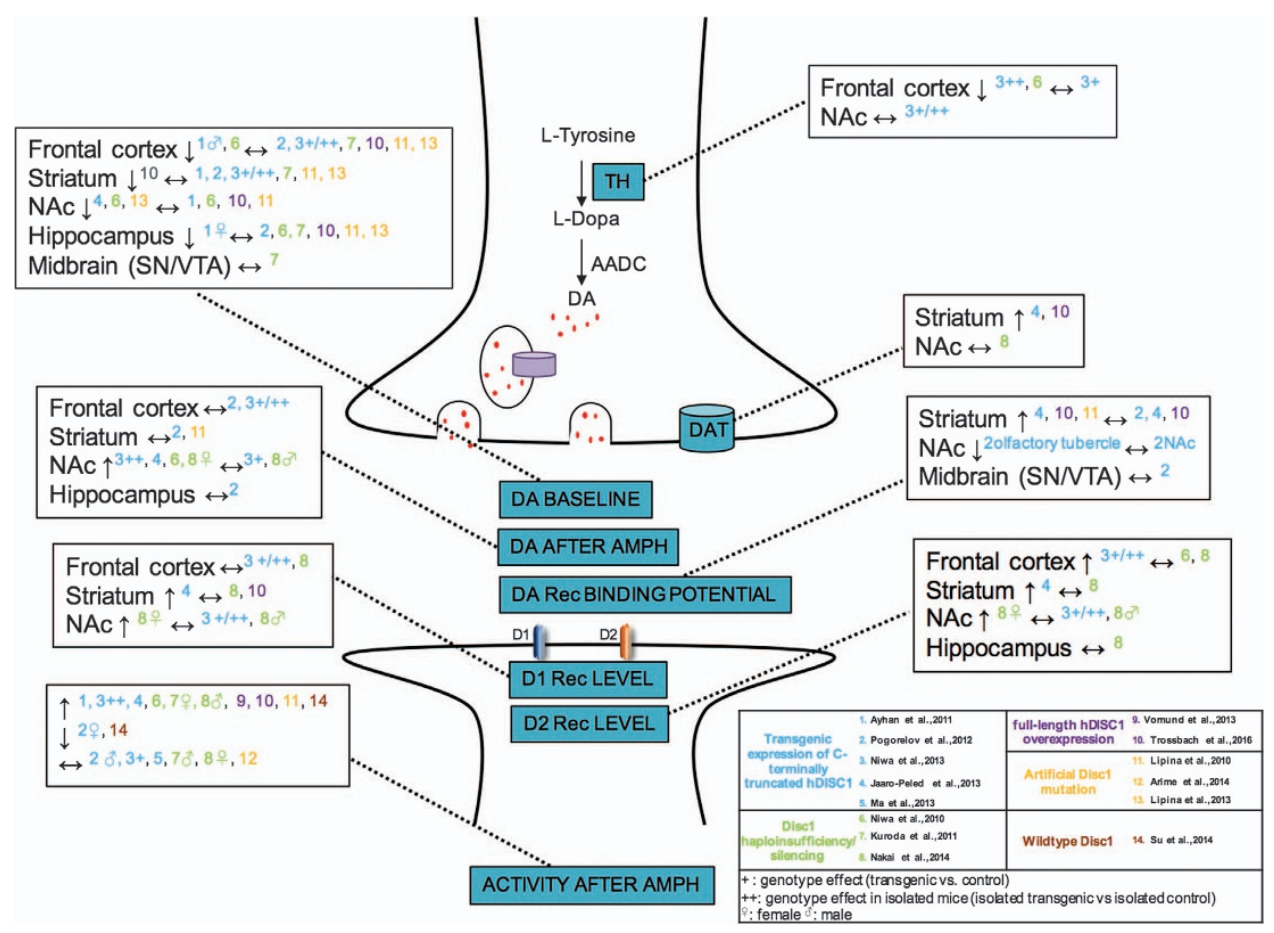

Figure 2. The impact of DISC1 models on the dopamine system. AMPH, amphetamine; DA, dopamine; DAT, dopamine transporter; NAC, nucleus accumbens; SN, substantia nigra; TH, tyrosine hydroxylase; VTA, ventral tegmental area.

using $\left[{ }^{3} \mathrm{H}\right]$ domperidone binding challenged with dopamine, but Trossbach et al. found no difference in $\left.{ }^{3} \mathrm{H}\right]$ raclopride binding by autoradiography. As raclopride does not distinguish low from high affinity or D2 from D3 receptors, taken together, these studies are consistent with a shift to the high-affinity state without a change in total D2/3 receptor levels. Jaaro-Peled et al..$^{52}$ found significantly increased binding potential of D2/3 receptor availability in the striatum using $\left[{ }^{11} \mathrm{C}\right]$ raclopride PET and significantly increased levels of $D 2 / 3 R$ in the medial part of the right rostral striatum using $\left[{ }^{3} \mathrm{H}\right]$ spiperone autoradiography but no significant differences in D2/3 levels in the total right rostral striatum and the lateral part of the right striatum in the hDISC1 compared with controls. Pogorelov et $a .^{50}$ found no significant difference in the rostral part of the striatum using $\left[{ }^{11} \mathrm{C}\right]$ raclopride autoradiography in the hDISC1 mice compared with controls.

Two studies investigated $\mathrm{D} 2 \mathrm{R}$ levels in the nucleus accumbens. ${ }^{51,56}$ One study found significantly increased $D 2 R$ levels in female but not male and mixed Disc1 $\Delta 2-3$ groups, ${ }^{56}$ whereas the other showed no significant differences. ${ }^{51}$

One study investigated D2/3R-binding potential in the nucleus accumbens using $\left[{ }^{11} \mathrm{C}\right]$ raclopride autoradiography PET and found no significant differences in the nucleus accumbens but significantly decreased levels in the right olfactory tubercle of female hDISC1 mice compared with controls. ${ }^{50}$ They used the same approach to investigate D2/3R-binding potential using $\left[{ }^{11} \mathrm{C}\right]$ raclopride autoradiography in the midbrain (substantia nigra/VTA) and found no significant difference between the $h D I S C 1$ and controls. ${ }^{50}$

One study investigated D2R levels in the hippocampus and found no significant difference between the Disc1 $\Delta 2-3$ haploinsufficiency and controls. ${ }^{56}$

\section{Locomotion after amphetamine administration}

Thirteen studies investigated locomotion after amphetamine administration. ${ }^{49-60,62}$ Ten studies found increased locomotion after amphetamine administration in the DISC1 models compared with control animals, in the pre- and postnatal $h D I S C 1$ expression groups, ${ }^{49}$ hDISC1 mice, ${ }^{52}$ the Disc1 RNAi/silencing model, ${ }^{54}$ female but not male Disc $1 \Delta 2-3$ mice, ${ }^{55}$ male but not female Disc $1 \Delta 2-3$ mice, ${ }^{56}$ full-length hDISC1-overexpressing rats, ${ }^{57,58}$ Disc1-L100P mice, ${ }^{59}$ isolated $h D I S C 1$ mice compared with isolated controls ${ }^{51}$ and wild-type Disc1 mice with no DISC1-D2R disruption. ${ }^{62}$ Two studies found decreased locomotion after amphetamine administration, in female but not male $h D I S C 1$ mice after escalating dose of methamphetamine treatment compared with controls in Pogorelov et al. ${ }^{50}$ and wild-type mice with Disc1-D2R disruption in Su et al. ${ }^{62}$ No significant changes were found in the hDISC1 mice and Disc1-L100P/L100P mice compared with controls in three studies. ${ }^{51,53,60}$

\section{DISCUSSION}

The main findings show that compared with controls, the DISC1 models exhibit reasonably consistent (1) increased locomotion after amphetamine administration (2) increased dopamine levels after amphetamine administration in the nucleus accumbens but (3) inconsistent alterations in basal dopamine levels and dopamine receptor levels and binding potentials. These findings extend other studies showing increased methamphetamineinduced dopamine release in the nucleus accumbens and locomotor hyperactivity in mice lacking DISC1-interacting proteins, such as fasciculation and elongation protein zeta $1^{64}$ and PDE $4{ }^{65}$ to indicate that the DISC1 pathway affects specific aspects of dopaminergic function.

Limitations

The findings presented in this systematic review must be considered in the light of the following limitations. First, the number of studies was modest for some aspects of dopaminergic function, such as transporter levels, and some regions. This limits the conclusions that can be drawn about these aspects, and highlights the needs for further studies. Second, the studies used a heterogeneous set of DISC1 models (Table 1), which could contribute to variability in results. Third, the evidence comes from a relatively small number of research groups. Thus, 







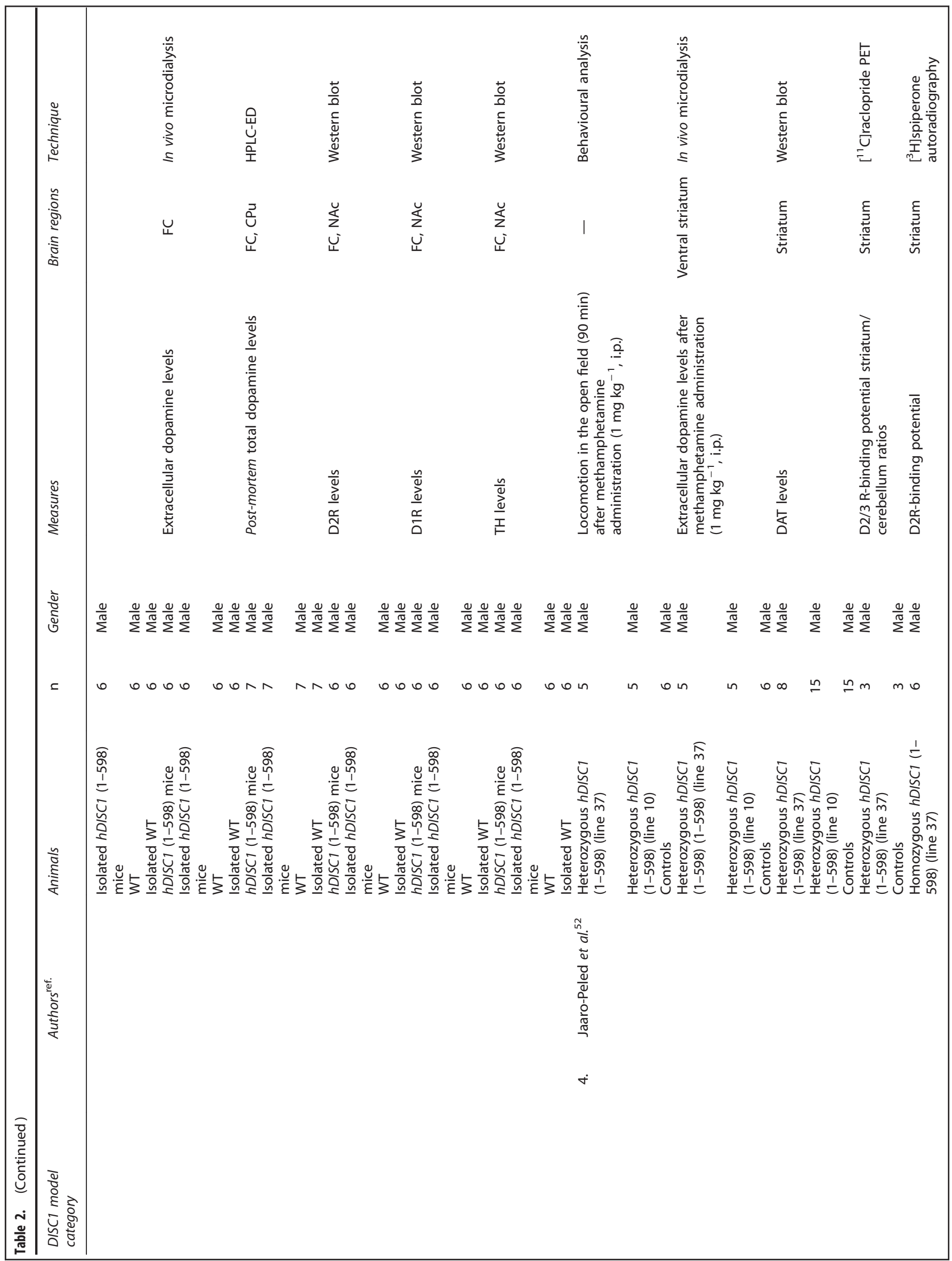




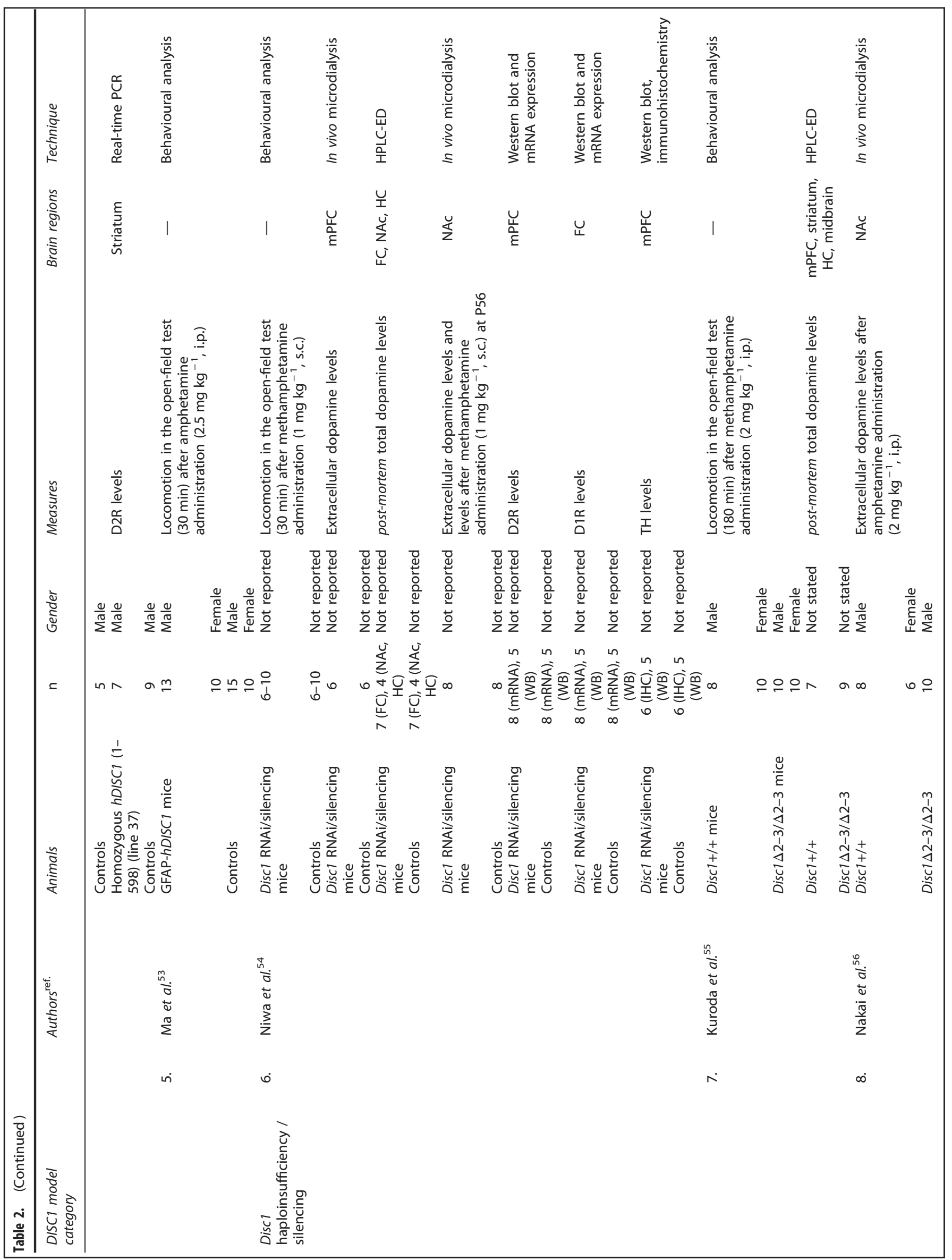




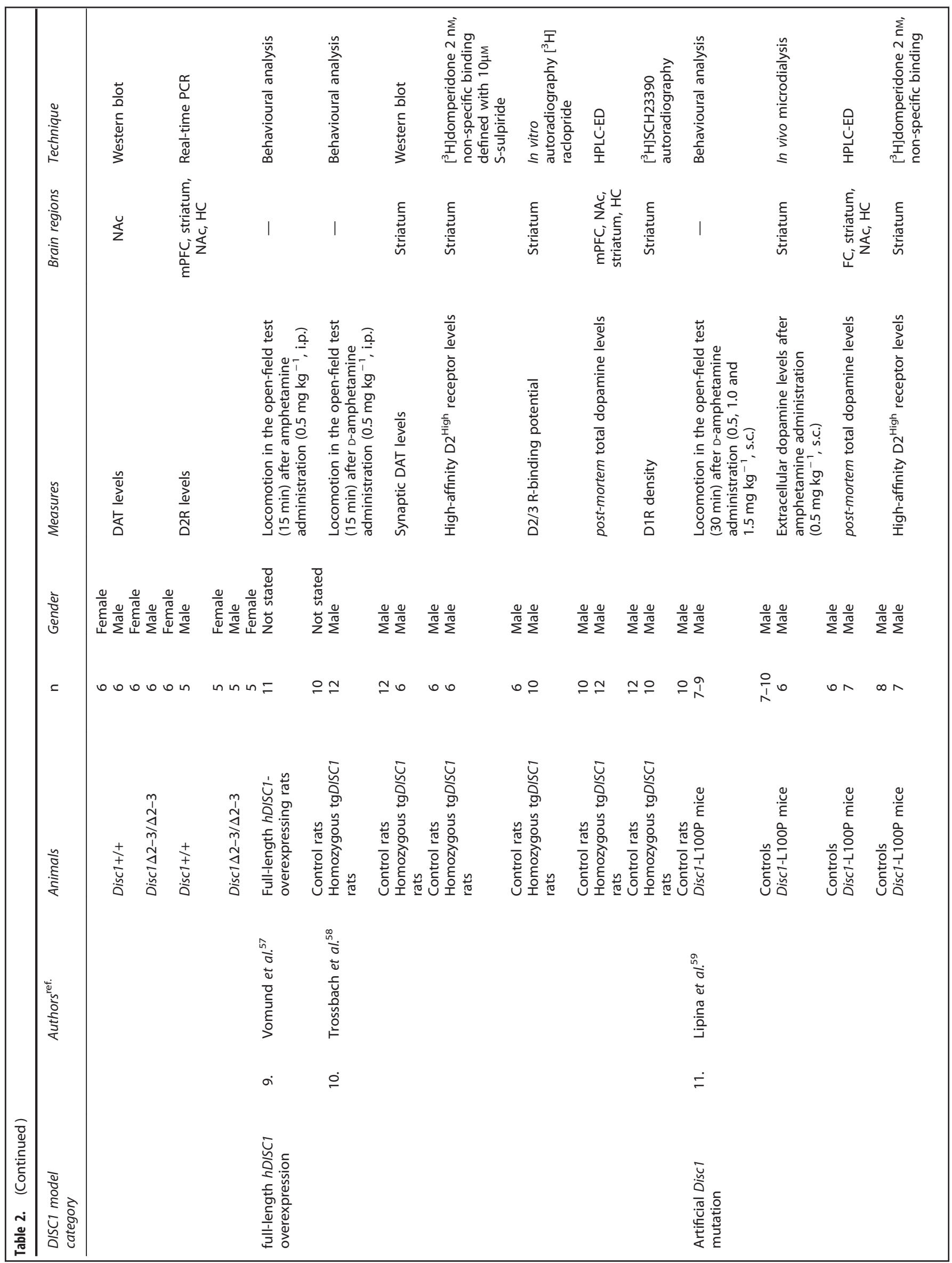


replication would be useful to determine generalisability. And fourth, alterations in other neurotransmitter system such as noradrenaline might also contribute to the locomotor hyperactivity phenotype observed. However, several reports indicate that locomotor hyperactivity after amphetamine is specifically mediated through dopamine and not noradrenergic transmission in the nucleus accumbens. ${ }^{66-68}$

Potential mechanisms underlying locomotor hyperactivity

The majority of the DISC1 models used showed locomotor hyperactivity following amphetamine challenge. This shows a relatively conserved phenotype of the DISC1 models that might be explained by (1) the presynaptic effects of DISC1 on dopamine release in the nucleus accumbens or (2) a direct impact of the DISC1 models on postsynaptic dopaminergic signal transduction, such as the protein serine/threonine protein kinase (Akt)glycogen synthase kinase-3 (GSK-3) pathway. In support of the first hypothesis, the nucleus accumbens is thought to have an important role in regulating locomotor activity. ${ }^{69,70}$ Local administration of dopamine and amphetamine has been shown to induce hyperactivity similar to systemic administration, ${ }^{66,70-72}$ and our review has identified reasonably consistent evidence that DISC1 models are associated with greater dopamine release to amphetamine. With regards to the second hypothesis, Akt and GSK-3 are two proteins regulated by DISC1 with respectively indirect and direct interactions. ${ }^{15,16,73}$ The Akt-GSK-3 pathway modulates dopamine neurotransmission and amphetaminemediated locomotor activity. ${ }^{74-76}$ Amphetamine/methamphetamine-induced dopamine release decreases Akt activation (phosphorylation state ${ }^{77}$ ), which activates GSK-3 by dephosphorylating the Serine 9 site $^{78}$ to modulate dopamine-dependent behaviours. $^{74}$ Although Disc1 wild-type protein decreases Akt and GSK-3 activation, ${ }^{15,73,79}$ the impact of mutant DISC1 on Akt and GSK-3 is less clear. Evidence shows increased and decreased Akt activation in DISC1 knockdown, ${ }^{15,62,80}$ no effects on Akt and GSK-3 levels in hDISC1 mice ${ }^{50}$ and consistently increased GSK-3 activation in DISC1 knockdown and Disc1 point mutation Q31L. ${ }^{62,81,82}$ Interestingly, mice overexpressing GSK-3 develop locomotor hyperactivity, ${ }^{83}$ GSK-3 knockdown mice express reduced locomotor activity ${ }^{84}$ and administration of GSK-3 inhibitor decreases amphetamine-induced hyperactivity. ${ }^{85}$

Potential mechanisms underlying increased dopamine release to amphetamine

The studies reporting increased dopamine levels following amphetamine administration in the nucleus accumbens used a Disc1 $12-3$ haploinsufficiency, ${ }^{56}$ a DN $h D I S C 1$ model in combination with adolescent isolation stress, ${ }^{51}$ a transient knockdown in prefrontal cortex ${ }^{54}$ and a DN hDISC 1 model targeting specifically pyramidal neurons of the cortex and hippocampus. ${ }^{52}$ This raises the questions of (1) the time course of changes in dopamine and whether there are developmental periods that are particularly vulnerable to DISC1 alterations, (2) the brain regions minimally required to lead to increased dopamine release to amphetamine, and in particular, the role of the cortical regions in regulating the nucleus accumbens dopamine levels.

With regards to the first point, recent studies suggest that DISC1 alterations interact with stress to impact on dopaminergic neurons during adolescence. ${ }^{51,86}$ These findings are in line with evidence showing that adolescence is a critical time life for the development of psychotic disorders including schizophrenia. ${ }^{87}$ With regards to the second point, a possible mechanism underlying increased dopamine levels in the nucleus accumbens could be a reduction in cortical parvalbumin-positive interneurons. Supporting this, studies have shown a decreased number of parvalbuminpositive interneurons in the cortex of DN DISC1 models. ${ }^{49,88-90}$ Parvalbumin-positive interneurons are GABAergic inhibitory 
Table 3. Findings

\begin{tabular}{|c|c|c|c|c|c|c|}
\hline & & $\begin{array}{l}\text { Frontal } \\
\text { cortex }\end{array}$ & Striatum & $\begin{array}{c}\text { NAc } \\
\text { (and OT) }\end{array}$ & $\begin{array}{c}\text { Midbrai } \\
\text { n (SN / } \\
\text { VTA) }\end{array}$ & $\begin{array}{l}\text { Hippocamp } \\
\text { us }\end{array}$ \\
\hline TH levels & & $\begin{array}{l}\downarrow 3^{++}, 6 \\
\leftrightarrow 3^{+}\end{array}$ & & $\leftrightarrow 3$ & & \\
\hline DAT levels & & & $\uparrow 4,10$ & $\leftrightarrow 8$ & & \\
\hline Dopamine & Total & $\begin{array}{l}\downarrow 1^{+}, 3^{++}, 6 \\
\leftrightarrow 2,3^{+} 7 \\
11,13\end{array}$ & $\begin{array}{l}\downarrow 10 \\
\leftrightarrow 1,2,3 \\
7,11,13\end{array}$ & $\begin{array}{l}\downarrow 13 \\
\leftrightarrow \\
6,11\end{array} 1^{\text {От }}$, & $\leftrightarrow 7$ & $\begin{array}{l}\downarrow 1^{\text {P Post }} \\
\leftrightarrow 6,11,7, \\
2,13,10\end{array}$ \\
\hline & $\begin{array}{l}\text { Extracellul } \\
\text { ar }\end{array}$ & $\begin{array}{l}\downarrow 6,3^{++} \\
\leftrightarrow 3^{+}\end{array}$ & $\leftrightarrow 11$ & $\downarrow 4,6$ & & \\
\hline Dopamine & Total & $\leftrightarrow 2$ & $\leftrightarrow 2$ & & & $\leftrightarrow 2$ \\
\hline $\begin{array}{l}\text { amphetami } \\
\text { ne }\end{array}$ & $\begin{array}{l}\text { Extracellul } \\
\text { ar }\end{array}$ & $\leftrightarrow 3$ & $\leftrightarrow 11$ & $\begin{array}{l}\uparrow 3^{++}, 4, \\
6,8^{0^{\prime}} \\
\leftrightarrow 3^{+}, 8^{0^{+}}\end{array}$ & & \\
\hline $\begin{array}{l}\text { Dopamine } \mathrm{F} \\
\text { Binding Pot }\end{array}$ & $\begin{array}{l}\text { eceptor } \\
\text { ntial }\end{array}$ & & $\begin{array}{l}\uparrow 4^{A, B}, \\
\stackrel{\leftrightarrow}{2^{E},} 4^{C, D}, \\
10^{F}\end{array}$ & $\begin{array}{l}\downarrow 2^{\text {क, OT }} \\
\leftrightarrow 2^{\text {\% }} \text { NAc }\end{array}$ & $\leftrightarrow 2$ & \\
\hline $\begin{array}{l}\text { D2 Recepto } \\
\text { state }\end{array}$ & affinity & & $\uparrow 10^{G}, 11$ & & & \\
\hline Dopamine & D1R & $\begin{array}{l}\overleftrightarrow{4} 3,8^{\text {d.n.s. }}, \\
10\end{array}$ & $\begin{array}{l}\uparrow 4 \\
\leftrightarrow 8^{\text {d.n.s. }}\end{array}$ & $\begin{array}{l}\uparrow 8^{\circ} \\
\leftrightarrow 3,8^{3}\end{array}$ & & \\
\hline $\begin{array}{l}\text { receptor } \\
\text { levels }\end{array}$ & D2R & 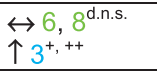 & $\begin{array}{l}\leftrightarrow_{4}^{\text {d.n.s. }} \\
\uparrow 4\end{array}$ & $\begin{array}{l}\uparrow 8^{\circ} \\
\leftrightarrow 3,8^{3}\end{array}$ & & $\leftrightarrow 8^{\text {d.n.s. }}$ \\
\hline $\begin{array}{l}\text { Locomotion } \\
\text { amphetamir } \\
\text { administrati }\end{array}$ & after & $\begin{array}{l}\uparrow 1_{1}^{\text {Pre+Post }}, 3^{++} \\
\downarrow 2^{\text {ED }}, 14^{\text {Disc }} \\
\leftrightarrow 2^{b^{B} \mathrm{ED},}, q_{\text {acut }}\end{array}$ & $\begin{array}{l}4,6,7^{\circ}, 8^{3}, \\
\text { D2R disruption } \\
3^{+}, 5^{\#}, 7^{3^{+}}, 8^{8}\end{array}$ & $\begin{array}{l}10,11,14 \\
12\end{array}$ & & \\
\hline$\uparrow:$ significar & higher in th & $\begin{array}{r}\text { DISC1 mode } \\
\text { signif }\end{array}$ & $\begin{array}{l}\text {;; } \downarrow \text { : significar } \\
\text { cant differenc }\end{array}$ & $\begin{array}{l}\text { tly lower in } \\
\text { e }\end{array}$ & the DISC1 & model; $\leftrightarrow$ : no \\
\hline $\begin{array}{l}{ }^{1} \text { Ayhan et a } \\
2 \text { Pogorelov } \\
3 \text { Niwa et al. } \\
{ }^{4} \text { Jaaro-Pele } \\
{ }^{5} \text { Ma et al., } 2 \\
{ }^{6} \text { Niwa et al. } \\
{ }^{7} \text { Kuroda et } \\
8 \text { Nakai et al } \\
{ }^{8} \text { Vomund e }\end{array}$ & $\begin{array}{l}\text {, } 2011 \\
\text { t al. } 2012 \\
2013 \\
\text { l et al., } 2013 \\
13 \\
2010 \\
\text { I., } 2011 \\
2014 \\
\text { al., } 2013\end{array}$ & $\begin{array}{l}\text { A: striatum } \\
\text { B: medial } p \\
\text { autoradiogr } \\
\text { C: total righ } \\
\text { D: lateral pe } \\
\text { autoradiogr } \\
\text { E: rostral pe } \\
\text { F: [11C]-rac } \\
\text { G: }\left[{ }^{3} \mathrm{H}\right]-\text { spip }\end{array}$ & $\begin{array}{l}{[11 \mathrm{C}] \text {-raclop }} \\
\text { art of the right } \\
\text { aphy } \\
\text { trostral striatu } \\
\text { irt of the right } \\
\text { aphy } \\
\text { it of the striat } \\
\text { lopride } \\
\text { erone }\end{array}$ & $\begin{array}{l}\text { ide PET } \\
\text { rostral stria } \\
\mathrm{m}-[3 \mathrm{H}]-\mathrm{sp} \\
\text { rostral striat } \\
\mathrm{um}-[11 \mathrm{C}]-\mathrm{rc}\end{array}$ & $\begin{array}{l}\text { um - }[3 \mathrm{H}]- \\
\text { perone aut } \\
\text { um - }[3 \mathrm{H}]-\mathrm{s} \\
\text { clopride }\end{array}$ & $\begin{array}{l}\text { piperone } \\
\text { oradiography } \\
\text { piperone }\end{array}$ \\
\hline${ }^{10}$ Trossbac & et al., 2016 & \#: astrocyte & -specific prom & otor & & \\
\hline${ }^{11}$ Lipina et & I. 2010 & d.n.s. : data & not shown & & & \\
\hline $\begin{array}{l}{ }^{12} \text { Arime et } \\
{ }^{13} \text { Lipina et } \\
{ }^{14} \text { Su et al., }\end{array}$ & $\begin{array}{l}., 2014 \\
., 2013 \\
014\end{array}$ & $\begin{array}{l}\text { DAT: dopar } \\
\text { ED: escalat } \\
\text { NAc : Nucle } \\
\text { Post: postn } \\
\text { Pre+Post: } \\
\text { TH: Tyrosin }\end{array}$ & $\begin{array}{l}\text { nine transport } \\
\text { ng dose of m } \\
\text { us accumben } \\
\text { atal expressio } \\
\text { re- and postn } \\
\text { e Hydroxylase }\end{array}$ & $\begin{array}{l}\text { r } \\
\text { group } \\
\text { gtal express }\end{array}$ & $\begin{array}{l}\text { mine treatn } \\
\text { ion group }\end{array}$ & ent \\
\hline & & $\begin{array}{l}+ \text { : genotyp } \\
++: \text { environ } \\
\text { nonisolated } \\
\text { }: \text { female } \\
\text { : male }\end{array}$ & $\begin{array}{l}\text { effect (contr } \\
\text { nental effect } \\
\end{array}$ & $\begin{array}{l}\text { vs. transg } \\
\text { n transgenic }\end{array}$ & $\begin{array}{l}\text { enic) } \\
\text { s (isolated }\end{array}$ & \\
\hline & & $\begin{array}{l}\text { blue }=\text { trans } \\
\text { green }=\text { Dis } \\
\text { orange }=\text { ar } \\
\text { purple }=\text { ful } \\
\text { brown }=\text { wil }\end{array}$ & $\begin{array}{l}\text { genic express } \\
\text { c1 haploinsuf } \\
\text { tificial Disc1 } \mathrm{n} \\
\text {-length hDISC } \\
\text { ttype Disc1 }\end{array}$ & $\begin{array}{l}\text { ion of C-ter } \\
\text { iciency / sile } \\
\text { lutation } \\
1 \text { overexpre }\end{array}$ & $\begin{array}{l}\text { minally trur } \\
\text { ncing } \\
\text { ssion }\end{array}$ & cated hDISC1 \\
\hline
\end{tabular}


neurons thought to regulate the dopaminergic activity in the nucleus accumbens and to have a role in schizophrenia through the modulation of cortical glutamate excitatory pyramidal neurons. ${ }^{91-93}$ Finally, the specific localisation of the findings in the nucleus accumbens might be related to an increased sensitivity of this region to stimulants, as it has been shown to release more dopamine following amphetamine administration compared with other striatal subdivisions. ${ }^{94}$

Inconsistent basal dopamine levels and dopamine receptorbinding potential and levels

We summarise here a series of inconsistent findings on basal dopamine levels and dopamine receptor-binding potentials and levels in the frontal cortex, striatum, nucleus accumbens and hippocampus. These findings might be due the heterogeneity of the DISC1 models used (Table 1). Among these, only the short interfering RNA knockdown or knockout models should have loss of function phenotypes whereas all others could have either loss of function, or gain of function, or combined phenotypes at the same time. However, no more consistency is observed when looking only at the loss of function models. It should also be noted that the $\operatorname{tgDISC1}$ rat was conceived as a model for protein pathology related to DISC1 rather than a model for mutant DISC 1. ${ }^{58,95}$ Another possible explanation could be that these are adaptive changes not always seen following the core dopamine release alteration.

\section{Implications}

The effects of DISC1 on dopamine release and the behavioural effects of amphetamine are in line with evidence showing increased amphetamine-induced dopamine release in schizophrenia, and that this positively correlates with amphetamine-induced positive psychotic symptoms. ${ }^{34,35,96,97}$ The absence of clear receptor changes is also consistent with the lack of changes in dopamine D2/3 receptors alterations seen in a meta-analysis of in vivo findings in schizophrenia. ${ }^{98}$ However, the inconsistent findings in striatal basal dopamine levels do not agree with the in vivo evidence showing increased basal dopamine levels in schizophrenia. ${ }^{33,99}$ Taken together, these findings indicate that DISC1 alterations may increase the risk of schizophrenia by dysregulating the presynaptic regulation of dopamine but they do not result in the full dopaminergic phenotype, suggesting other factors must interact with DISC1. Stress is one likely candidate factor $^{100}$ that has been shown increase dopamine release in psychosis. $^{38}$

It should be noted that DISC1 is also associated with affective disorders including major depression. ${ }^{101,102}$ The implications of the findings for this association remains unclear, as human PET studies have shown decreased dopamine synthesis capacity in patients with major depression particularly in individuals with reduced affect or psychomotor slowing symptoms ${ }^{103-105}$ and some endophenotypes such as anhedonia are thought to be underlined by dopamine function. ${ }^{106,107}$

Our conclusions drawn from the preclinical research reviewed here may have interesting implications for clinical research and hence translational value at pointing to the necessity of identifying a biomarker to identify illness subtypes related to DISC1 dysfunction, to guide treatment choice and as a lead for the development of novel therapies. Determining whether DISC1 function is aberrant in a given individual could be a useful to subtype patients. Given that aberrant DISC1 function modulates aspects of dopaminergic function, this may help identify patients who may be responsive to drugs that act on the dopaminergic system, in line with emerging evidence on dopaminergic and nondopaminergic subtypes of schizophrenia. ${ }^{108}$ What directions could the search for identifying biomarkers for aberrant DISC1 function take? Screening for DISC1 polymorphisms may be one way to assess this as some polymorphisms have been associated with different neuronal functions and with treatment-resistant schizophrenia. ${ }^{109-111}$ As it has been demonstrated that singlenucleotide polymorphisms of DISC1-interacting genes are overrepresented in schizophrenia, ${ }^{112}$ the use of a DISC1-interactome polygenic risk score might also be a complementary approach to stratify the risk associated with a specific signalling pathway or response to treatment. However, it should be recognised that genetic diagnostics alone may not provide sufficient information because DISC1 levels also depend on other factors, for example, BACE1-dependent cleavage of neuregulin $1 .{ }^{113}$ Large cohort studies of patients are needed to determine whether DISC1 polymorphisms and/or DISC1 protein levels in peripheral cells do identify subsets of patients with distinct illness characteristics or treatment response. ${ }^{114}$ This may require the combinatorial analysis of blood-based, imaging and/or neurophysiological factors, to both identify those patients with both aberrant DISC1 and neuronal function. Another key implication is that understanding how DISC1 alterations lead to dopamine dysregulation could identify new treatment approaches to address the dopamine dysfunction seen in schizophrenia and people at risk of schizophrenia in a broader sense. Pharmacological targeting of aberrant DISC1 function may be able to correct dopamine dysfunction without directly interfering with dopamine receptors themselves, providing an alternative to existing antipsychotic drugs, which are all D2/3 receptor blockers. In that sense, clinical development of diagnostics and pharmacotherapy of DISC1related disorders may go hand in hand ${ }^{95}$ to support the development of precision medicine in psychiatry.

\section{Future directions}

We identify four key lines of direction for future studies based on the findings: first, as results to date come from a relative small number of studies, it would be useful to investigate dopamine function in DISC1 models recently developed. ${ }^{47,48}$ Second, the mechanism by which DISC1 leads to increased dopamine release to amphetamine needs further investigation, in particular to determine whether this could be mediated by disinhibition of parvalbumin-positive interneurons or the Akt-GSK-3 pathway. Interestingly, a DISC1 model has been recently developed with selective knockdown of interneuronal DISC1 in parvalbumin neurons, ${ }^{47}$ which might provide insightful knowledge on the mechanisms linking DISC1 and dopamine regulations. In that context, it is also remarkable that DISC1 as a single factor is able to both regulate dopamine neuroanatomy as well as parvalbuminpositive interneuron placement in cortical layers. ${ }^{115}$ Third, elevated dopamine synthesis capacity is the other aspect of presynaptic dopamine dysregulation widely linked to schizophrenia and people at risk of schizophrenia. ${ }^{36,37,116}$ Thus, future work should test if DISC1 alterations affect this aspect of presynaptic dopamine function in humans. Fourth, it would be useful to examine further the impact of environmental stress on dopamine release and dopamine levels in DISC1 models as proposed by some authors. ${ }^{51,117}$

\section{CONCLUSIONS}

Compared with controls, the majority of the DISC1 models but not all exhibits (1) increased locomotion after amphetamine administration and (2) increased dopamine levels after amphetamine administration in the nucleus accumbens but (3) inconsistent basal dopamine levels and dopamine receptor levels and binding potentials. This suggests that presynaptic dopamine dysregulation is a potential mechanism for the increased rates of psychotic disorders seen in the original DISC1 families and DISC1 variant carriers, and identifies a number of potential therapeutic targets 
for treating or even preventing schizophrenia based on the DISC1 pathway.

\section{CONFLICT OF INTEREST}

NJB is a full-time employee and a shareholder in AstraZeneca plc. ODH has received investigator-initiated research funding from and/or participated in advisory/speaker meetings organised by AstraZeneca, Autifony, BMS, Eli Lilly, Heptares, Jansenn, Lundbeck, Lyden-Delta, Otsuka, Servier, Sunovion, Rand and Roche. The remaining authors declare no conflict of interest.

\section{ACKNOWLEDGMENTS}

This work was supported by a EU-FP7 MC-ITN IN-SENS grant (grant number 607616) to TD, NJB, CK and ODH, a NARSAD/BBR Independent Investigator Award (grant number 20350) and a grant from the Forschungskommission of the Medical Faculty/ Heinrich Heine University Düsseldorf (\#9772569) to CK, a Medical Research Council (UK) grant (grant number MC-A656-5QD30), a Maudsley Charity Grant (grant number 666) and the National Institute for Health Research (NIHR) Biomedical Research Centre at South London and Maudsley NHS Foundation Trust and King's College London to $\mathrm{ODH}$.

\section{DISCLAIMER}

Neither Dr Howes nor his family have been employed by or have holdings/a financial stake in any biomedical company. The views expressed are those of the authors and not necessarily those of the NHS, the NIHR or the Department of Health.

\section{REFERENCES}

1 Jacobs $\mathrm{P}$, Brunton M, Frackiewicz A, Newton M, Cook P, Robson E. Studies on a family with three cytogenetic markers. Ann Hum Genet 1970; 33: 325-336.

2 St Clair D, Blackwood D, Muir W, Carothers A, Walker M, Spowart G et al. Association within a family of a balanced autosomal translocation with major mental illness. Lancet 1990; 336: 13-16.

3 Sachs NA, Sawa A, Holmes SE, Ross CA, DeLisi LE, Margolis RL. A frameshift mutation in Disrupted in Schizophrenia 1 in an American family with schizophrenia and schizoaffective disorder. Mol Psychiatry 2005; 10: 758-764.

4 Thomson PA, Duff B, Blackwood DH, Romaniuk L, Watson A, Whalley HC et al Balanced translocation linked to psychiatric disorder, glutamate, and cortical structure/function. NPJ Schizophr 2016; 2: 16024

5 Johnstone M, Thomson PA, Hall J, Mclntosh AM, Lawrie SM, Porteous DJ. DISC1 in schizophrenia: genetic mouse models and human genomic imaging. Schizophr Bull 2011; 37: 14-20.

6 Tomoda T, Sumitomo A, Jaaro-Peled H, Sawa A. Utility and validity of DISC1 mouse models in biological psychiatry. Neuroscience 2016; 321: 99-107.

7 Porteous DJ, Thomson PA, Millar JK, Evans KL, Hennah W, Soares DC et al. DISC1 as a genetic risk factor for schizophrenia and related major mental illness: response to Sullivan. Mol Psychiatry 2014; 19: 141-143.

8 Sullivan PF. Questions about DISC1 as a genetic risk factor for schizophrenia. Mol Psychiatry 2013; 18: 1050-1052.

9 Niwa M, Cash-Padgett T, Kubo KI, Saito A, Ishii K, Sumitomo A et al. DISC1 a key molecular lead in psychiatry and neurodevelopment: No-More Disrupted-inSchizophrenia 1. Mol Psychiatry 2016; 21: 1488-1489.

10 Brandon NJ, Sawa A. Linking neurodevelopmental and synaptic theories of mental illness through DISC1. Nat Rev Neurosci 2011; 12: 707-722.

11 Porteous DJ, Millar JK, Brandon NJ, Sawa A. DISC1 at 10: connecting psychiatric genetics and neuroscience. Trends Mol Med 2011; 17: 699-706.

12 Kang E, Burdick KE, Kim JY, Duan X, Guo JU. Sailor KA, et al. Interaction between FEZ1 and DISC1 in regulation of neuronal development and risk for schizophrenia. Neuron 2011; 72: 559-571.

13 Soda T, Frank C, Ishizuka K, Baccarella A, Park YU, Flood Z et al. DISC1-ATF4 transcriptional repression complex: dual regulation of the CAMP-PDE4 cascade by DISC1. Mol Psychiatry 2013; 18: 898-908.

14 Millar JK, Pickard BS, Mackie S, James R, Christie S, Buchanan SR et al. DISC1 and PDE4B are interacting genetic factors in schizophrenia that regulate CAMP signaling. Science 2005; 310: 1187-1191.

15 Kim JY, Duan X, Liu CY, Jang MH, Guo JU, Pow-anpongkul N et al. DISC1 regulates new neuron development in the adult brain via modulation of AKT-mTOR signaling through KIAA1212. Neuron 2009; 63: 761-773.
16 Rodriguez-Seoane C, Ramos A, Korth C, Requena JR. DISC1 regulates expression of the neurotrophin VGF through the PI3K/AKT/CREB pathway. I Neurochem 2015; 135: 598-605.

17 Hayashi-Takagi A, Takaki M, Graziane N, Seshadri S, Murdoch H, Dunlop AJ et al. Disrupted-in-Schizophrenia 1 (DISC1) regulates spines of the glutamate synapse via Rac1. Nat Neurosci 2010; 13: 327-332.

18 Wang Q, Charych El, Pulito VL, Lee JB, Graziane NM, Crozier RA et al. The psychiatric disease risk factors DISC1 and TNIK interact to regulate synapse composition and function. Mol Psychiatry 2011; 16: 1006-1023.

19 Kamiya A, Tan PL, Kubo Kl, Engelhard C, Ishizuka K, Kubo A et al. Recruitment of PCM1 to the centrosome by the cooperative action of DISC1 and BBS4 - A candidate for psychiatric illnesses. Arch Gen Psychiatry 2008; 65: 996-1006.

20 Ishizuka K, Kamiya A, Oh EC, Kanki H, Seshadri S, Robinson JF et al. DISC1dependent switch from progenitor proliferation to migration in the developing cortex. Nature 2011; 473: 92-U107.

21 Hikida T, Gamo NJ, Sawa A. DISC1 as a therapeutic target for mental illnesses. Expert Opin Ther Targets 2012; 16: 1151-1160.

22 Sawa A, Ishizuka K, Katsanis N. The potential of DISC1 protein as a therapeutic target for mental illness. Expert Opin Ther Targets 2016; 20: 641-643.

23 Soares DC, Carlyle BC, Bradshaw NJ, Porteous DJ. DISC1: Structure, Function, and Therapeutic Potential for Major Mental Illness. ACS Chem Neurosci 2011; 2: 609-632.

24 Howes OD, Murray RM. Schizophrenia: an integrated sociodevelopmentalcognitive model. Lancet 2014; 383: 1677-1687.

25 Lyon GJ, Abi-Dargham A, Moore H, Lieberman JA, Javitch JA, Sulzer D. Presynaptic regulation of dopamine transmission in schizophrenia. Schizophr Bull 2011; 37: 108-117.

26 Heinz A, Schlagenhauf F. Dopaminergic dysfunction in schizophrenia: salience attribution revisited. Schizophr Bull 2010; 36: 472-485.

27 Seeman $\mathrm{P}$, Lee $\mathrm{T}$, Chau-Wong $\mathrm{M}$, Wong K. Antipsychotic drug doses and neuroleptic/dopamine receptors. Nature 1976; 261: 717-719.

28 Creese I, Burt DR, Snyder SH. Dopamine receptors and average clinical doses. Science 1976; 194: 546

29 van Rossum JM. The significance of dopamine-receptor blockade for the mechanism of action of neuroleptic drugs. Arch Int Pharmacodyn Ther 1966; 160: 492-494.

30 Berman SM, Kuczenski R, McCracken JT, London ED. Potential adverse effects of amphetamine treatment on brain and behavior: a review. Mol psychiatry 2009; 14: $123-142$.

31 Grant KM, LeVan TD, Wells SM, Li M, Stoltenberg SF, Gendelman HE et al. Methamphetamine-associated psychosis. J Neuroimmune Pharmacol 2012; 7: 113-139.

32 Howes O, McCutcheon R, Stone J. Glutamate and dopamine in schizophrenia: an update for the 21st century. J Psychopharmacol 2015; 29: 97-115.

33 Abi-Dargham A, Rodenhiser J, Printz D, Zea-Ponce Y, Gil R, Kegeles LS et al. Increased baseline occupancy of D2 receptors by dopamine in schizophrenia. Proc Natl Acad Sci USA 2000; 97: 8104-8109.

34 Breier A, Su TP, Saunders R, Carson RE, Kolachana BS, de Bartolomeis A et al. Schizophrenia is associated with elevated amphetamine-induced synaptic dopamine concentrations: evidence from a novel positron emission tomography method. Proc Natl Acad Sci USA 1997; 94: 2569-2574.

35 Laruelle M, Abi-Dargham A, van Dyck CH, Gil R, D'Souza CD, Erdos J et al. Single photon emission computerized tomography imaging of amphetamine-induced dopamine release in drug-free schizophrenic subjects. Proc Natl Acad Sci USA 1996; 93: 9235-9240.

36 Howes OD, Montgomery AJ, Asselin MC, Murray RM, Valli I, Tabraham P et al. Elevated striatal dopamine function linked to prodromal signs of schizophrenia. Arch Gen Psychiatry 2009; 66: 13-20.

37 Egerton A, Chaddock CA, Winton-Brown TT, Bloomfield MA, Bhattacharyya S, Allen $P$ et al. Presynaptic striatal dopamine dysfunction in people at ultra-high risk for psychosis: findings in a second cohort. Biol Psychiatry 2013; 74: 106-112.

38 Mizrahi R, Addington J, Rusjan PM, Suridjan I, Ng A, Boileau I et al. Increased stress-induced dopamine release in psychosis. Biol Psychiatry 2012; 71: 561-567.

39 Mizrahi R, Kenk M, Suridjan I, Boileau I, George TP, McKenzie K et al. Stressinduced dopamine response in subjects at clinical high risk for schizophrenia with and without concurrent cannabis use. Neuropsychopharmacology 2014; 39 : 1479-1489.

40 Howes OD, Williams M, Ibrahim K, Leung G, Egerton A, McGuire PK et al. Midbrain dopamine function in schizophrenia and depression: a post-mortem and positron emission tomographic imaging study. Brain 2013; 136(Pt 11): 3242-3251.

41 Kegeles LS, Slifstein M, Xu X, Urban N, Thompson JL, Moadel T et al. Striatal and extrastriatal dopamine D2/D3 receptors in schizophrenia evaluated with [18 F] fallypride positron emission tomography. Biol pPsychiatry 2010; 68: 634-641.

42 Kambeitz J, Abi-Dargham A, Kapur S, Howes OD. Alterations in cortical and extrastriatal subcortical dopamine function in schizophrenia: systematic review and meta-analysis of imaging studies. Br J Psychiatry 2014; 204: 420-429. 
43 Featherstone RE, Kapur S, Fletcher PJ. The amphetamine-induced sensitized state as a model of schizophrenia. Prog Neuropsychopharmacol Biol Psychiatry 2007; 31: 1556-1571.

44 Joel D, Weiner I. The connections of the dopaminergic system with the striatum in rats and primates: an analysis with respect to the functional and compartmental organization of the striatum. Neuroscience 2000; 96: 451-474.

45 Weinstein JJ, Chohan MO, Slifstein M, Kegeles LS, Moore H, Abi-Dargham A. PathwaySpecific Dopamine Abnormalities in Schizophrenia. Biol Psychiatry 2016; 81: 31-42.

46 Salgado S, Kaplitt MG. The nucleus accumbens: a comprehensive review. Stereotact Funct Neurosurg 2015; 93: 75-93.

47 Seshadri S, Faust T, Ishizuka K, Delevich K, Chung Y, Kim SH et al. Interneuronal DISC1 regulates NRG1-ErbB4 signalling and excitatory-inhibitory synapse formation in the mature cortex. Nat Commun 2015; 6: 10118.

48 Shahani N, Seshadri S, Jaaro-Peled H, Ishizuka K, Hirota-Tsuyada Y, Wang Q et al. DISC1 regulates trafficking and processing of APP and Abeta generation. Mol Psychiatry 2015; 20: 874-879.

49 Ayhan Y, Abazyan B, Nomura J, Kim R, Ladenheim B, Krasnova IN et al. Differential effects of prenatal and postnatal expressions of mutant human DISC1 on neurobehavioral phenotypes in transgenic mice: evidence for neurodevelopmental origin of major psychiatric disorders. Mol Psychiatry 2011; 16: 293-306.

50 Pogorelov VM, Nomura J, Kim J, Kannan G, Ayhan Y, Yang C et al. Mutant DISC1 affects methamphetamine-induced sensitization and conditioned place preference: a comorbidity model. Neuropharmacology 2012; 62: 1242-1251.

51 Niwa M, Jaaro-Peled H, Tankou S, Seshadri S, Hikida T, Matsumoto $\mathrm{Y}$ et al. Adolescent stress-induced epigenetic control of dopaminergic neurons via glucocorticoids. Science 2013; 339: 335-339.

52 Jaaro-Peled H, Niwa M, Foss CA, Murai R, de Los Reyes S, Kamiya A et al. Subcortical dopaminergic deficits in a DISC1 mutant model: a study in direct reference to human molecular brain imaging. Hum Mol Genet 2013; 22: 1574-1580.

53 Ma TM, Abazyan S, Abazyan B, Nomura J, Yang C, Seshadri S et al. Pathogenic disruption of DISC1-serine racemase binding elicits schizophrenia-like behavior via D-serine depletion. Mol Psychiatry 2013; 18: 557-567.

54 Niwa M, Kamiya A, Murai R, Kubo K, Gruber AJ, Tomita K et al. Knockdown of DISC1 by in utero gene transfer disturbs postnatal dopaminergic maturation in the frontal cortex and leads to adult behavioral deficits. Neuron 2010; 65: 480-489.

55 Kuroda K, Yamada S, Tanaka M, lizuka M, Yano H, Mori D et al. Behavioral alterations associated with targeted disruption of exons 2 and 3 of the Disc1 gene in the mouse. Hum Mol Genet 2011; 20: 4666-4683.

56 Nakai T, Nagai T, Wang R, Yamada S, Kuroda K, Kaibuchi K et al. Alterations of GABAergic and dopaminergic systems in mutant mice with disruption of exons 2 and 3 of the Disc1 gene. Neurochem Int 2014; 74: 74-83.

57 Vomund S, Sapir T, Reiner O, Silva MA, Korth C. Generation of topically transgenic rats by in utero electroporation and in vivo bioluminescence screening. $J$ Vis Exp 2013; 79: e50146.

58 Trossbach SV, Bader V, Hecher L, Pum ME, Masoud ST, Prikulis I et al. Misassembly of full-length Disrupted-in-Schizophrenia 1 protein is linked to altered dopamine homeostasis and behavioral deficits. Mol Psychiatry 2016; 21: 1561-1572.

59 Lipina TV, Niwa M, Jaaro-Peled H, Fletcher PJ, Seeman P, Sawa A et al. Enhanced dopamine function in DISC1-L100P mutant mice: implications for schizophrenia. Genes Brain Behav 2010; 9: 777-789.

60 Arime Y, Fukumura R, Miura I, Mekada K, Yoshiki A, Wakana S et al. Effects of background mutations and single nucleotide polymorphisms (SNPs) on the Disc1 L100P behavioral phenotype associated with schizophrenia in mice. Behav Brain Funct 2014; 10: 45.

61 Lipina TV, Fletcher PJ, Lee FH, Wong AH, Roder JC. Disrupted-in-schizophrenia-1 Gln31Leu polymorphism results in social anhedonia associated with monoaminergic imbalance and reduction of CREB and beta-arrestin-1,2 in the nucleus accumbens in a mouse model of depression. Neuropsychopharmacology 2013; 38: 423-436.

62 Su P, Li S, Chen S, Lipina TV, Wang M, Lai TK et al. A dopamine D2 receptor-DISC1 protein complex may contribute to antipsychotic-like effects. Neuron 2014; 84: 1302-1316.

63 Seeman P. Nomenclature of central and peripheral dopaminergic sites and receptors. Biochem Pharmacol 1982; 31: 2563-2569.

64 Sakae N, Yamasaki N, Kitaichi K, Fukuda T, Yamada M, Yoshikawa H et al. Mice lacking the schizophrenia-associated protein FEZ1 manifest hyperactivity and enhanced responsiveness to psychostimulants. Hum Mol Genet 2008; 17: 3191-3203.

65 Siuciak JA, McCarthy SA, Chapin DS, Martin AN. Behavioral and neurochemical characterization of mice deficient in the phosphodiesterase-4B (PDE4B) enzyme. Psychopharmacology 2008; 197: 115-126.
66 Pijnenburg AJ, Honig WM, Van der Heyden JA, Van Rossum JM. Effects of chemical stimulation of the mesolimbic dopamine system upon locomotor activity. Eur J Pharmacol 1976; 35: 45-58.

67 Roberts DC, Zis AP, Fibiger HC. Ascending catecholamine pathways and amphetamine-induced locomotor activity: importance of dopamine and apparent non-involvement of norepinephrine. Brain Res 1975; 93: 441-454.

68 Kelly PH, Iversen SD. Selective 6OHDA-induced destruction of mesolimbic dopamine neurons: abolition of psychostimulant-induced locomotor activity in rats. Eur J Pharmacol 1976; 40: 45-56.

69 Russo SJ, Mazei-Robison MS, Ables JL, Nestler EJ. Neurotrophic factors and structural plasticity in addiction. Neuropharmacology 2009; 56(Suppl 1): 73-82.

70 Sellings LH, Clarke PB. Segregation of amphetamine reward and locomotor stimulation between nucleus accumbens medial shell and core. J Neurosci 2003; 23: 6295-6303.

71 Costall B, Domeney AM, Naylor RJ. Locomotor hyperactivity caused by dopamine infusion into the nucleus accumbens of rat brain: specificity of action. Psychopharmacology 1984; 82: 174-180.

72 Campbell A, Villavicencio AT, Yeghiayan SK, Balikian R, Baldessarini RJ. Mapping of locomotor behavioral arousal induced by microinjections of dopamine within nucleus accumbens septi of rat forebrain. Brain Res 1997; 771: 55-62.

73 Mao Y, Ge X, Frank CL, Madison JM, Koehler AN, Doud MK et al. Disrupted in schizophrenia 1 regulates neuronal progenitor proliferation via modulation of GSK3beta/beta-catenin signaling. Cell 2009; 136: 1017-1031.

74 Beaulieu JM, Gainetdinov RR, Caron MG. Akt/GSK3 signaling in the action of psychotropic drugs. Ann Rev Pharmacol Toxicol 2009; 49: 327-347.

75 Beaulieu JM. A role for Akt and glycogen synthase kinase- 3 as integrators of dopamine and serotonin neurotransmission in mental health. $J$ Psychiatry Neurosci 2012; 37: 7-16.

76 Beaulieu JM, Sotnikova TD, Marion S, Lefkowitz RJ, Gainetdinov RR, Caron MG. An Akt/beta-arrestin 2/PP2A signaling complex mediates dopaminergic neurotransmission and behavior. Cell 2005; 122: 261-273.

77 Manning BD, Cantley LC. AKT/PKB signaling: navigating downstream. Cell 2007; 129: $1261-1274$.

78 Bhat RV, Shanley J, Correll MP, Fieles WE, Keith RA, Scott CW et al. Regulation and localization of tyrosine216 phosphorylation of glycogen synthase kinase-3beta in cellular and animal models of neuronal degeneration. Proc Natl Acad Sci USA 2000; 97: 11074-11079.

79 Dachtler J, Elliott C, Rodgers RJ, Baillie GS, Clapcote SJ. Missense mutation in DISC1 C-terminal coiled-coil has GSK3beta signaling and sex-dependent behavioral effects in mice. Sci Rep 2016; 6: 18748.

80 Hashimoto R, Numakawa T, Ohnishi T, Kumamaru E, Yagasaki $\mathrm{Y}$, Ishimoto T et al. Impact of the DISC1 Ser704Cys polymorphism on risk for major depression, brain morphology and ERK signaling. Hum Mol Genet 2006; 15 : 3024-3033.

81 Gancarz A, Jouroukhin Y, Saito A, Shevelkin A, Mueller LE, Kamiya A et al. DISC1 signaling in cocaine addiction: Towards molecular mechanisms of co-morbidity. Neurosci Res 2015; 105: 70-74.

82 Lipina TV, Wang M, Liu F, Roder JC. Synergistic interactions between PDE4B and GSK-3: DISC1 mutant mice. Neuropharmacology 2012; 62: 1252-1262.

83 Prickaerts J, Moechars D, Cryns K, Lenaerts I, van Craenendonck H, Goris I et al. Transgenic mice overexpressing glycogen synthase kinase 3beta: a putative model of hyperactivity and mania. J Neurosci 2006; 26: 9022-9029.

84 Beaulieu JM, Sotnikova TD, Yao WD, Kockeritz L, Woodgett JR, Gainetdinov RR et al. Lithium antagonizes dopamine-dependent behaviors mediated by an AKT/ glycogen synthase kinase 3 signaling cascade. Proc Natl Acad Sci USA 2004; 101: 5099-5104.

85 Gould TD, Einat H, Bhat R, Manji HK. AR-A014418, a selective GSK-3 inhibitor, produces antidepressant-like effects in the forced swim test. Int J Neuropsychopharmacol 2004; 7: 387-390.

86 Niwa M, Lee RS, Tanaka T, Okada K, Kano S, Sawa A. A critical period of vulnerability to adolescent stress: epigenetic mediators in mesocortical dopaminergic neurons. Hum Mol Genet 2016; 25: 1370-1381.

87 Owen MJ, Sawa A, Mortensen PB. Schizophrenia. Lancet 2016; 388: 86-97.

88 Hikida T, Jaaro-Peled H, Seshadri S, Oishi K, Hookway C, Kong S et al. Dominantnegative DISC1 transgenic mice display schizophrenia-associated phenotypes detected by measures translatable to humans. Proc Natl Acad Sci USA 2007; 104: 14501-14506.

89 Ibi D, Nagai T, Koike H, Kitahara Y, Mizoguchi H, Niwa M et al. Combined effect of neonatal immune activation and mutant DISC1 on phenotypic changes in adulthood. Behav Brain Res 2010; 206: 32-37.

90 Shen S, Lang B, Nakamoto C, Zhang F, Pu J, Kuan SL et al. Schizophrenia-related neural and behavioral phenotypes in transgenic mice expressing truncated Disc1. J Neurosci 2008; 28: 10893-10904. 
91 Del Arco A, Mora F. Prefrontal cortex-nucleus accumbens interaction: in vivo modulation by dopamine and glutamate in the prefrontal cortex. Pharmacol Biochem Behav 2008; 90: 226-235.

92 Jackson ME, Frost AS, Moghaddam B. Stimulation of prefrontal cortex at physiologically relevant frequencies inhibits dopamine release in the nucleus accumbens. J Neurochem 2001; 78: 920-923.

93 Nakazawa K, Zsiros V, Jiang Z, Nakao K, Kolata S, Zhang S et al. GABAergic interneuron origin of schizophrenia pathophysiology. Neuropharmacology 2012; 62: 1574-1583.

94 Martinez D, Slifstein M, Broft A, Mawlawi O, Hwang DR, Huang Y et al. Imaging human mesolimbic dopamine transmission with positron emission tomography. Part Il: amphetamine-induced dopamine release in the functional subdivisions of the striatum. J Cereb Blood Flow Metab 2003; 23: 285-300.

95 Korth C. Aggregated proteins in schizophrenia and other chronic mental diseases: DISC1opathies. Prion 2012; 6: 134-141.

96 Laruelle M, Abi-Dargham A, Gil R, Kegeles L, Innis R. Increased dopamine transmission in schizophrenia: relationship to illness phases. Biol Psychiatry 1999; 46: $56-72$.

97 Abi-Dargham A, Gil R, Krystal J, Baldwin RM, Seibyl JP, Bowers M et al. Increased striatal dopamine transmission in schizophrenia: confirmation in a second cohort. Am J Psychiatry 1998; 155: 761-767.

98 Howes OD, Kambeitz J, Kim E, Stahl D, Slifstein M, Abi-Dargham A et al. The nature of dopamine dysfunction in schizophrenia and what this means for treatment. Arch Gen Psychiatry 2012; 69: 776-786.

99 Kegeles LS, Abi-Dargham A, Frankle WG, Gil R, Cooper TB, Slifstein M et al. Increased synaptic dopamine function in associative regions of the striatum in schizophrenia. Arch Gen Psychiatry 2010; 67: 231-239.

100 Howes OD, Murray RM. Schizophrenia: an integrated sociodevelopmentalcognitive model. Lancet 2014; 383: 1677-1687.

101 Thomson PA, Maclntyre DJ, Hamilton G, Dominiczak A, Smith BH, Morris A et al. Association of DISC1 variants with age of onset in a population-based sample of recurrent major depression. Mol Psychiatry 2013; 18: 745-747.

102 Chubb JE, Bradshaw NJ, Soares DC, Porteous DJ, Millar JK. The DISC locus in psychiatric illness. Mol Psychiatry 2008; 13: 36-64.

103 Agren H, Reibring L PET. studies of presynaptic monoamine metabolism in depressed patients and healthy volunteers. Pharmacopsychiatry 1994; 27: 2-6.

104 Bragulat V, Paillere-Martinot ML, Artiges E, Frouin V, Poline JB, Martinot JL. Dopaminergic function in depressed patients with affective flattening or with impulsivity: [18 F]fluoro-L-dopa positron emission tomography study with voxelbased analysis. Psychiatry Res 2007; 154: 115-124.

105 Martinot M, Bragulat V, Artiges E, Dolle F, Hinnen F, Jouvent R et al. Decreased presynaptic dopamine function in the left caudate of depressed patients with affective flattening and psychomotor retardation. Am J Psychiatry 2001; 158: 314-316

106 Argyropoulos SV, Nutt DJ. Anhedonia revisited: is there a role for dopaminetargeting drugs for depression? J Psychopharmacol 2013; 27: 869-877.
107 Treadway MT, Zald DH. Reconsidering anhedonia in depression: lessons from translational neuroscience. Neurosci Biobehav Rev 2011; 35: 537-555.

108 Mouchlianitis E, McCutcheon R, Howes OD. Brain-imaging studies of treatment-resistant schizophrenia: a systematic review. Lancet Psychiatry 2016; 3: 451-463.

109 Whalley HC, Sussmann JE, Johnstone M, Romaniuk L, Redpath H, Chakirova G et al. Effects of a mis-sense DISC1 variant on brain activation in two cohorts at high risk of bipolar disorder or schizophrenia. Am J Med Genet B Neuropsychiatr Genet 2012; 159B: 343-353.

110 Mouaffak F, Kebir O, Chayet M, Tordjman S, Vacheron MN, Millet B et al. Association of Disrupted in Schizophrenia 1 (DISC1) missense variants with ultraresistant schizophrenia. Pharmacogenomics J 2011; 11: 267-273.

111 Duff BJ, Macritchie KA, Moorhead TW, Lawrie SM, Blackwood DH. Human brain imaging studies of DISC1 in schizophrenia, bipolar disorder and depression: a systematic review. Schizophr Res 2013; 147: 1-13.

112 Costas J, Suarez-Rama JJ, Carrera N, Paz E, Paramo M, Agra S et al. Role of DISC1 interacting proteins in schizophrenia risk from genome-wide analysis of missense SNPs. Ann Hum Genet 2013; 77: 504-512.

113 Seshadri S, Kamiya A, Yokota Y, Prikulis I, Kano S, Hayashi-Takagi A et al. Disrupted-in-Schizophrenia-1 expression is regulated by beta-site amyloid precursor protein cleaving enzyme-1-neuregulin cascade. Proc Natl Acad Sci USA 2010; 107: 5622-5627.

114 Trossbach SV, Fehsel K, Henning U, Winterer G, Luckhaus C, Schable S et al. Peripheral DISC1 protein levels as a trait marker for schizophrenia and modulating effects of nicotine. Behav Brain Res 2014; 275: 176-182.

115 Hamburg H, Trossbach SV, Bader V, Chwiesko C, Kipar A, Sauvage M et al. Simultaneous effects on parvalbumin-positive interneuron and dopaminergic system development in a transgenic rat model for sporadic schizophrenia. Scientific Reports 2016; 6: 34946.

116 Meyer-Lindenberg A, Miletich RS, Kohn PD, Esposito G, Carson RE, Quarantelli M et al. Reduced prefrontal activity predicts exaggerated striatal dopaminergic function in schizophrenia. Nat Neurosci 2002; 5: 267-271.

117 Cash-Padgett T, Jaaro-Peled H. DISC1 mouse models as a tool to decipher geneenvironment interactions in psychiatric disorders. Front Behav Neurosci 2013; 7: 113.

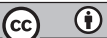

This work is licensed under a Creative Commons Attribution 4.0 International License. The images or other third party material in this article are included in the article's Creative Commons license, unless indicated otherwise in the credit line; if the material is not included under the Creative Commons license, users will need to obtain permission from the license holder to reproduce the material. To view a copy of this license, visit http://creativecommons.org/licenses/ by/4.0/

(c) The Author(s) 2017 